\title{
CAFFEINE INTAKE IN HUNGARY - A POPULATION BASED ESTIMATION
}

\author{
A. LugASI ${ }^{\mathrm{a}, \mathrm{b} *}$, M. BAKACS ${ }^{\mathrm{a}}$ and É. MARTOS ${ }^{\mathrm{a}}$

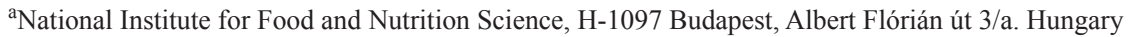 \\ ${ }^{\mathrm{b}}$ Budapest Business School, College of Commerce, Catering and Tourism, Department of Catering, \\ H-1054 Budapest, Alkotmány utca 9-11. Hungary
}

(Received: 19 August 2013; accepted: 20 March 2014)

\begin{abstract}
Caffeine is a bitter, white crystalline xanthine alkaloid that is synthesized in different parts of more than 60 plant species. In a previous study, caffeine content of 377 food samples obtained from the Hungarian market was measured by a validated HPLC technique. These analytical data were built up into a food composition database called NutriComp. Dietary caffeine intake of the Hungarian population was estimated based on the data of the National Nutritional Status Survey 2009. Daily caffeine intake of Hungarian adult males and females were $147 \pm 6.2 \mathrm{mg}$ per capita (95\% CI: $135-160)$, and $138 \pm 4.2 \mathrm{mg}$ per capita (95\% CI: 129-147), respectively. There was no significant difference between genders. The oldest men and women consumed significantly less caffeine than the people between 35-64 years of age. The main sources of caffeine are coffee and tea with $58-59 \%$, and $35-37 \%$ of the total intake in men and women, respectively.
\end{abstract}

Keywords: caffeine, coffee, tea, intake, sources

Caffeine is a white crystalline xanthine alkaloid having bitter taste. Different parts of around 60 plant species contain caffeine, including coffee. Caffeine can be found not only in beans, but leaves, and also fruit (Frary et al., 2005; LeE \& Balick, 2006; DellacasSa et al., 2007). Some caffeine containing plant materials like coffee and cacao beans, tea leaves contain other alkaloids of the xanthine group as theobromine and theophylline (PIzzA et al., 1999).

Caffeine is also found in different food products produced from natural sources like coffee drinks, cola drinks, tea products, chocolates, cocoa, cacao based sweets, and so on. Caffeine is also used in other products, such as soda, energy drinks, and some medicines (FrARY et al., 2005).

Dietary intake of caffeine varies widely in the world. In Canada STAVRIC and co-workers (1988) reported 49-1022 mg intake per day. In the USA $4 \mathrm{mg} \mathrm{kg}^{-1}$ body weight was calculated as the daily dietary intake by BARONE and ROBERTS (1996), which equates to $280 \mathrm{mg} / \mathrm{d}$ for a $70 \mathrm{~kg}$ person, whereas FrARY and co-workers (2005) reported $193 \mathrm{mg} /$ person. Caffeine intake is lower in children than in adults, with a mean daily intake of 14-22 mg for children between 1 and 9 years of age in the USA (KNIGHT et al., 2004). Intake is likely to be higher in older children and adolescents, with the majority coming from soft drinks (VALEK et al., 2004). Approximately $90 \%$ of adults report regular caffeine use, with an average daily intake of 227 mg (FRARY et al., 2005). The top three sources of caffeine in adults are coffee $(70 \%)$, soda $(16 \%)$, and tea (12\%) (FrARY et al., 2005).

\footnotetext{
* To whom correspondence should be addressed. Phone: +36-1-374 6266; e-mail: lugasi.andrea@kvifk.bgf.hu
} 
The daily intake of $4 \mathrm{mg} / \mathrm{kg}$ bw in the United States is very comparable to the average in the UK of $3.98 \mathrm{mg} / \mathrm{kg}$ bw/day. These levels are higher than the consumption in the Republic of Ireland, which $214 \mathrm{mg} / \mathrm{d}$ for a $70 \mathrm{~kg}$ person (Fredholm et al., 1999; KNIGHT et al., 2004). The reported intake in Denmark is much higher with an average of $7 \mathrm{mg} / \mathrm{kg}$ bw/day (NAwroT et al., 2003).

In the northern part of Europe as Iceland, Sweden, and Denmark, 235, 425, and $490 \mathrm{mg}$ caffeine intake was observed, respectively (Office of Food ICELAND, 2004; NCM, 2002). In Portugal the dietary intake of caffeine varied between 4.7 and $200 \mathrm{mg}$, while in Japan $256 \mathrm{mg}$ for women and $268 \mathrm{mg}$ for men were reported (YAMADA et al., 2009; Lino \& PENA, 2010).

Based on the data adapted from the 1995 food balance sheets of the Food and Agriculture Organization of the United Nations (FAO) the dietary intake of caffeine in different countries is summarized in Table 1 (Fredholm et al., 1999; HeCKMAN et al., 2010).

\begin{tabular}{lc} 
Table 1. Average daily caffeine consumption according to the literature* \\
\hline Country & Adults (mg/day/capita) \\
\hline China & 16 \\
South Africa & 40 \\
Kenya & 50 \\
United States & 168 \\
Japan & 169 \\
United Kingdom & 202 \\
Canada & 210 \\
Australia & 232 \\
France & 239 \\
Switzerland & 288 \\
Brazil & 300 \\
Finland & 329 \\
Denmark & 390 \\
\hline
\end{tabular}

*This data was adapted from the 1995 food balance sheets of the Food and Agriculture Org. of the United Nations (FAO) (Fredholm et al., 1999).

Because of caffeine's ubiquity, it is rarely thought of as a problematic drug. The primary effect of caffeine is to relieve fatigue and enhance mental performance. Low dose of caffeine produces stimulation (DALY \& Fredholm, 1998). Caffeine increases alertness, can elevate mood and reduces fatigue (Leinart \& Huber 1966; Smith, 2002). Normal consumption improves performance on tasks that require alertness (SмIтн, 2002). 
Excessive ingestion causes a state of intoxication named as caffeinism, which is typified by restlessness, excitement, rambling thought and speech, agitation, and insomnia. The acute toxic level of caffeine is not established, but for adults it is about $10 \mathrm{~g} /$ day, which is comparable to consuming near 100 cups of coffee (NAWrot et al., 2003). Excessive consumption of caffeine by children and adolescents has been supposed as a cause of headache, which usually passes after withdrawal (HERING-HANIT \& GADOTH, 2003). Caffeine is also in connection with sleep disturbances, shorter nocturnal sleep duration, increased wake time and increased daytime sleep (Pollak \& Bright, 2003).

The total daily intake, as well as the leading food source of caffeine, varies throughout the world. Leading human studies conducted in the past decade has demonstrated that caffeine consumption less than $400 \mathrm{mg} /$ day causes no significant health risks to most consumers (NAwrot et al., 2003).

In a previous study the caffeine content of more than 370 food items were measured, and data were published (LugAsI et al., 2015). The aim of the present study is to develop a caffeine database including the types and forms of caffeine containing beverages and foods based on our earlier data and then identify the main caffeine sources, calculate their consumed amount, and finally estimate the dietary intake of caffeine among the Hungarian adult population using a 3-day dietary record. All parts of this study were done at the National Institute for Food and Nutrition Science.

\section{Materials and methods}

\subsection{Caffeine database}

Caffeine data from the analytical results were built into an existing computer system called NutriComp. The NutriComp is a well-known, well-designed, and easy to use nutrient intake assessment and diet planning software in Hungary, used by several private and public companies and authorities in the field of food industry, public health, food safety, and catering. Caffeine content of different food items that were built into the database of the software are summarized in Table 2. Based on these data the caffeine content of several complex foods was also calculated.

\subsection{Dietary intake assessment}

The nutritional assessment was based on a 3-day dietary record (including two nonconsecutive workdays and one Sunday) within a 2 -week period. Dietary records were given by randomly chosen Hungarian adults, age $>18 \mathrm{y}$, representative for age, gender, and size of living place, total number were 1131. Each individual record was checked and the food items were coded by an experienced dietician. The caffeine intake was estimated in the whole group, in two genders, and in three age groups (18-34 y, 35-64 y, > 65 y) of both genders. Intake data calculated here is the estimated intake for the whole Hungarian adult population. The data were processed by a computer programme (NutriComp), based on the Hungarian Nutrient Database. This work was a part of the National Nutrition and Nutritional Status Survey (OTÁP2009), details of which were published elsewhere (LugAsi et al., 2012a, 2012b; MARTOS et al., 2012a, 2012b; SARKADI NAGY et al., 2012). For the correction of sampling error and lack of response error post weighting has been applied. For population estimates we have used STATA 9.2 (survey module), where we provided 95\% confidence interval and standard error. 
Table 2. Analytical data built into the database of NutriComp software

\begin{tabular}{|c|c|}
\hline Food item & $\begin{array}{l}\text { Caffeine content } \\
\quad(\mathrm{mg} / 100 \mathrm{~g})\end{array}$ \\
\hline Ground coffee powder with normal caffeine level & 1890 \\
\hline Instant coffee & 3950 \\
\hline Black tea leaves & 2000 \\
\hline Cacao powder & 104 \\
\hline Cacao powder, instant & 28 \\
\hline Instant tea powder & 1794 \\
\hline Pudding powder with cacao & 29 \\
\hline Milk chocolate & 15.4 \\
\hline Dark chocolate & 77 \\
\hline Biscuit, wafer & 11.6 \\
\hline Breakfast cereals with cacao & 10.2 \\
\hline \multicolumn{2}{|l|}{ Special Hungarian cakes } \\
\hline Pound-cake & 2.1 \\
\hline Sweet cake & 2.3 \\
\hline Muesli bar with chocolate & 0.2 \\
\hline Linzer with cocoa and vanilla & 4.7 \\
\hline Waffle with cocoa & 8.3 \\
\hline Semi-prepared powder for home-made cake with cocoa powder & 5 \\
\hline Semi-prepared powder for home-made chocolate cream & 29 \\
\hline Ice cream & 7.4 \\
\hline \multicolumn{2}{|l|}{ Drinks } \\
\hline Milk with cocoa & 2.4 \\
\hline Milk with coffee & 16 \\
\hline Cola, normal, light & 12 \\
\hline Coffee drink, espresso & 160 \\
\hline Black tea drink & 32 \\
\hline
\end{tabular}

\subsection{Assessment of caffeine sources}

The main caffeine sources were defined with the help of the data retrieved from NutriComp software. The system is suited to separate the different caffeine sources because of the appropriate data settings of the 3 days dietary records. 


\section{Results and discussion}

\subsection{Dietary caffeine intake of the Hungarian population}

Daily caffeine intake of Hungarian adult males and females was $147 \pm 6.2 \mathrm{mg}$ per capita $(95 \%$ CI: $135-160$ ), and $138 \pm 4.2 \mathrm{mg}$ per capita (95\% CI: 129-147), respectively (Table 3 ). There was no significant difference between genders. Adults between 34 and 64 years of both genders consume the highest amount of caffeine, male $165 \mathrm{mg}$ day $^{-1}$, female $150 \mathrm{mg}$ day ${ }^{-1}$. Lower intakes were observed among the younger and older adult groups of both genders. There are significant differences between the age groups with the highest and the lowest caffeine daily intake either in men or women (165 vs $121 \mathrm{mg}$ for male, $150 \mathrm{vs} 109 \mathrm{mg}$ for female).

Table 3. Dietary intake of caffeine in the Hungarian adult population, mg/day/capita

\begin{tabular}{|c|c|c|c|c|c|c|c|c|}
\hline \multirow[b]{3}{*}{ Total } & \multicolumn{4}{|c|}{ Male } & \multicolumn{4}{|c|}{ Female } \\
\hline & \multirow{2}{*}{$\begin{array}{c}\text { Mean } \\
147\end{array}$} & \multirow{2}{*}{$\begin{array}{l}\text { SE } \\
6.2\end{array}$} & \multicolumn{2}{|c|}{$\begin{array}{c}95 \% \text { confidence } \\
\text { interval }\end{array}$} & \multirow{2}{*}{$\begin{array}{r}\text { Mean } \\
138\end{array}$} & \multirow{2}{*}{$\begin{array}{l}\text { SE } \\
4.2\end{array}$} & \multicolumn{2}{|c|}{$\begin{array}{l}95 \% \text { confidence } \\
\text { interval }\end{array}$} \\
\hline & & & 135 & 160 & & & 129 & 147 \\
\hline $18-34 \mathrm{y}$ & 131 & 10.9 & 109 & 152 & 140 & 9.6 & 121 & 159 \\
\hline $35-64 y$ & 165 & 8.7 & 147 & 182 & 150 & 5.2 & 140 & 160 \\
\hline$\geq 65 y$ & 121 & 9.9 & 101 & 141 & 109 & 7.2 & 95 & 123 \\
\hline
\end{tabular}

The proportions of caffeine intake among caffeine sources are demonstrated in Fig. 1. The main source of caffeine both in case of men and women is coffee with $58 \%$ and $59 \%$ of the total intake. Lower intake rate could be observed in case of tea and ice tea $35 \%$ and $37 \%$ in men and women, respectively) and cola drinks (5\% and $2 \%$ for men and women, in the same order). Sweets, chocolates, cocoa drinks, cakes, and breakfast cereals represent very low rate in the intake of caffeine, around or less than $1 \%$.

\section{Conclusions}

In the present study, we developed a comprehensive caffeine database, which contained beverages and solid foods available on the Hungarian market.

The total daily intake as well as the leading source of caffeine vary throughout the world depending on the dietary habits. Dietary intake of caffeine in Hungary seems to be significantly lower than the data reported by other countries, including the US, Canada, Ireland, Denmark, Iceland, and so on (StAVric et al., 1988; Barone \& RoberTs, 1996; NCM, 2002; NAWrot et al., 2003; Office of Food Iceland, 2004; Frary et al., 2005). Assuming that one cup of coffee contains about $80 \mathrm{mg}$ of caffeine, the average Hungarian consumer consumes around two cups of coffee per day. 


\section{Cocoa;}

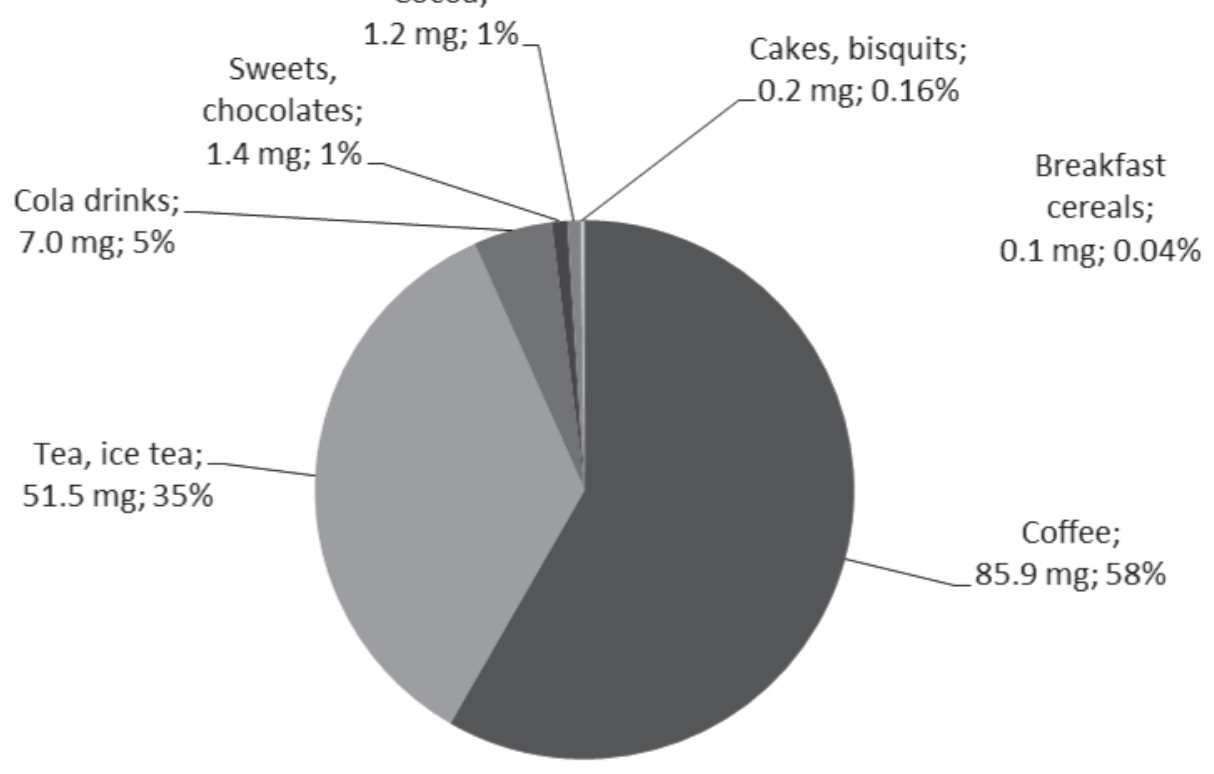

Men: $147 \pm 6.2 \mathrm{mg} /$ day/capita

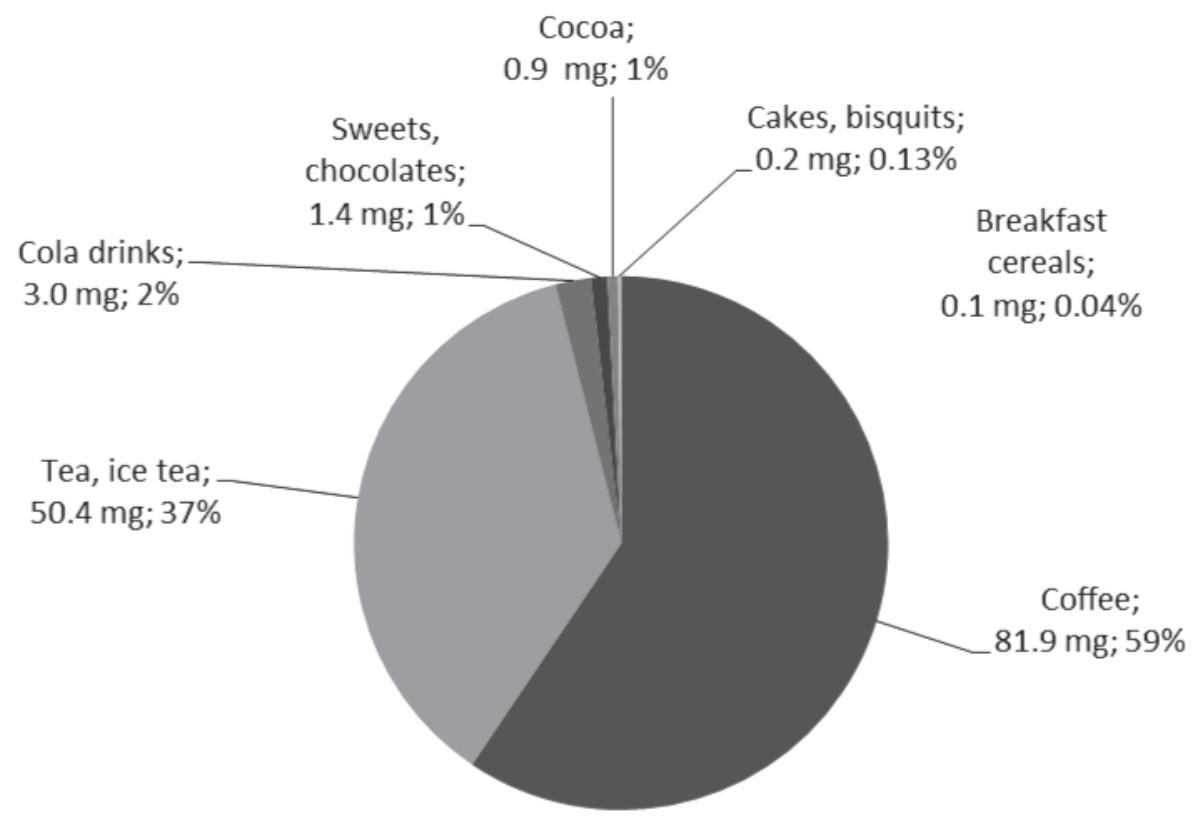

Women: $138 \pm 4.2 \mathrm{mg} /$ day/capita

Fig. 1. Profile of caffeine intake 
The average Hungarian intake has not changed significantly since the last dietary survey carried out in 2003-2004. In that population level survey, the daily caffeine intake for the total investigated population $(n=1179)$, for men $(n=473)$, and for women $(n=706)$ were 158 $\mathrm{mg}, 150 \mathrm{mg}$, and $164 \mathrm{mg}$ per capita, respectively (RODLER et al., 2005). In that study the oldest male consumed the lowest level of caffeine (111 mg per day) but the oldest female the highest (191 mg per day), unlike the present study, where the oldest segment of the population consumed the least caffeine - see Fig 2. In 2009 another dietary survey was carried out in Hungary, where caffeine intake was also estimated. In that study the caffeine intake of males and females were $100 \mathrm{mg}$ per day, and $102 \mathrm{mg}$ per day, respectively. There were no significant differences among genders and age groups (SzEITZ-SzABÓ et al., 2011).

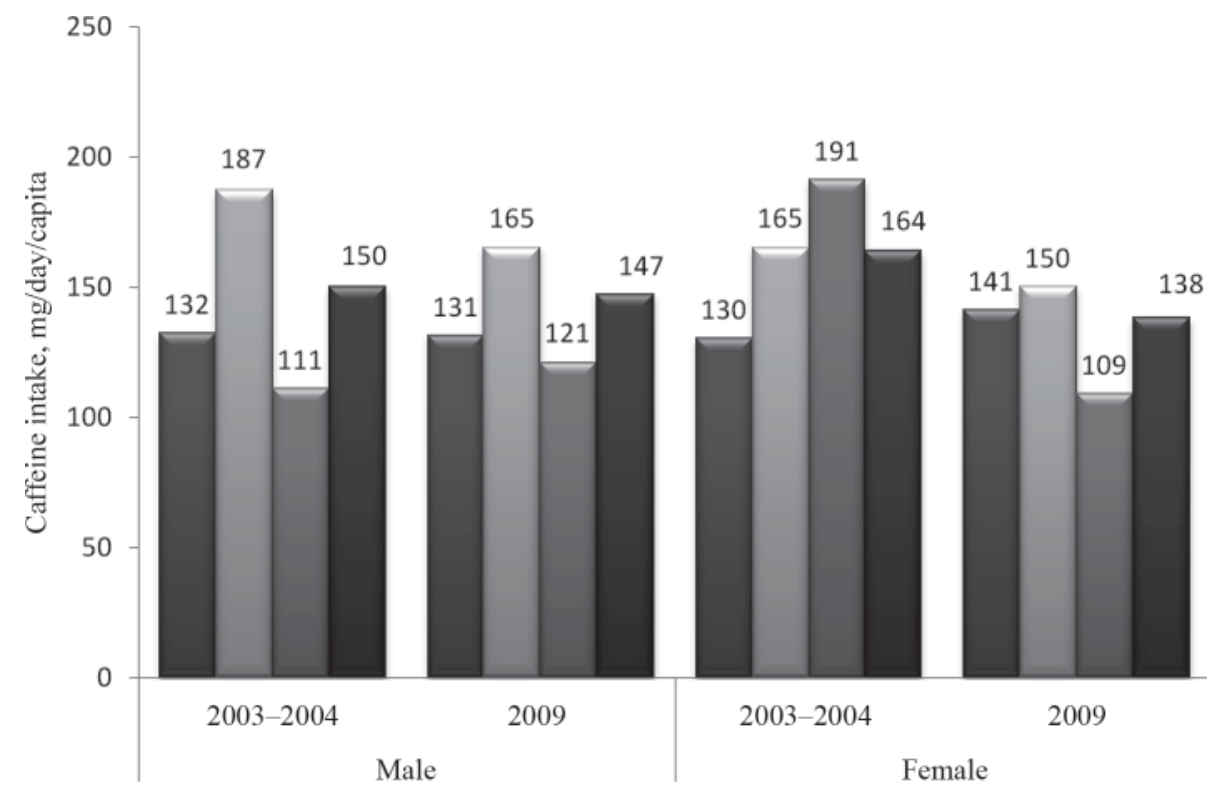

Fig. 2. Dietary caffeine intake in Hungary in 2003-2004 and in 2009; $\square: 18-34$ year in 2009; : 35-59 in 2003-2004, 35-64 year in 2009; : $: \geq 60$ in 2003-2004, $\geq 65$ year in 2009; $\square$ : total

Since data from the present Hungarian nutrition survey showed that the average consumption of caffeine from all sources is within the limits of $400 \mathrm{mg}$ per day found by NAwROT and co-workers (2003), it is not to be associated with adverse effects such as general toxicity, cardiovascular effects, effects on bone health, and changes in adult behaviour, the caffeine intake of adults does not give any reason for a public health concern.

\section{References}

Barone, J.J. \& Roberts, H.R. (1996): Caffeine consumption. Food Chem. Toxicol., 34, 19-129.

Daly, J.W. \& Fredholm, B.B. (1998): Caffeine - an atypical drug of dependence. Drug Alcohol Depen., 51, 199206.

Dellacassa, E.C., Cesio, V., Vázquez, A., Echeverry, S., Soule, S., Ferreira, F. \& Heinzen, H. (2007): Yerba mate. Historia, uso y propiedades. (Mate tea. History, usage and properties.) Rev. Asoc. Quím. Farmac. Uruguay, 51, 1620. 
Frary, C.D., Johson, R.K. \& Wang, M.Q. (2005): Food sources and intakes of caffeine in the diets of persons in the United States. J. Am. Diet. Assoc., 105, 110-113.

Fredholm, B.B., Battig, K., Holmen, J., Nehlig, A. \& Zvartau, E.E. (1999): Actions of caffeine in the brain with special reference to factors that contribute to its widespread use. Pharma Rev., 51, 83-133.

Heckman, M., Weil, J. \& Gonzalez Demejia, E. (2010): Caffeine (1, 3, 7-trimethylxanthine) in foods: A comprehensive review on consumption, functionality, safety, and regulatory matters. J. Food Sci., 75, 77-87.

Hering-Hanit, R. \& Gadoth, N. (2003): Caffeine-induced headache in children and adolescents. Cephalalgia, 23, $332-335$.

Knight, C.A., Knight, I., Mitchell, D.C. \& Zepp, J.E. (2004): Beverage caffeine intake in US consumers and subpopulations of interest: estimates from the Share of Intake Panel survey. Food Chem. Toxicol., 42, 19231930.

LeE, R.A. \& BALick, M.J. (2006): Rx: Caffeine. Explore, 2, 55-59.

Leinart, G.A. \& Huber, H.P. (1966): Differential effects of coffee on speed and power tests. J. Psych. Interdisc. Appl., 63, 269-274.

Lino, C.M. \& PenA, A. (2010): Occurrence of caffeine, saccharin, benzoic acid and sorbic acid in soft drinks and nectars in Portugal and subsequent exposure assessment. Food Chem., 121, 503-508.

Lugasi, A., Bakacs, M., Zentai, A., Kovács, V.A. \& Martos, É. (2012a): Országos Táplálkozás és Tápláltsági Állapot Vizsgálat - OTÁP2009. III. A magyar lakosság vitamin-bevitele (Hungarian Diet and Nutritional Status Survey - The OTAP2009 study. III. Vitamin intake of the Hungarian population). Orvosi Hetilap, 153(28), 1106-1117.

Lugasi, A., SArkadi Nagy, E., Zentai, A., Bakacs, M., Illés, É., Baldauf, Zs. \& Martos, É. (2012b): Országos Táplálkozás és Tápláltsági Állapot Vizsgálat - OTÁP2009. V. A magyar lakosság nyomelem-bevitele. (Hungarian Diet and Nutritional Status Survey - The OTAP2009 study. V. Trace element intake of the Hungarian population). Orvosi Hetilap, 153(30), 1177-1184.

Lugasi, A., KádÁr, G., Alb. K., Schreiber Molnár, E. \& Martos, É. (2015): Caffeine content of conventional and non conventional foods on the Hungarian market. Acta Alimentaria, 44, 86-94.

Martos, É., Kovács, V.A., BaKacs, M., KaposvÁri, Cs. \& Lugasi, A. (2012a): Országos Táplálkozás- és Tápláltsági Állapot Vizsgálat - OTÁP 2009. I. A magyar lakosság tápláltsági állapota. (Hungarian Diet and Nutritional Status Survey - The OTAP2009 study. I. Nutritional status of the Hungarian population). Orvosi Hetilap, 153, 1023-1030.

Martos, É., Bakacs, M., SArkadi Nagy, E., Ráczkevy, T., Zentai, A., Baldauf, Zs., Illés, É. \& Lugasi, A. (2012b): Országos Táplálkozás és Tápláltsági Állapot Vizsgálat - OTÁP2009. IV. A magyar lakosság makroelem bevitele (Hungarian Diet and Nutritional Status Survey - The OTAP2009 study. IV. Minerals intake of the Hungarian population). Orvosi Hetilap, 153(29), 1132-1141.

Nawrot, P., Jordan, S., Eastwood, J., Rotstein, J., Hugenholtz, A. \& Feely, M. (2003): Effects of caffeine on human health. Food Addit. Contam., 20, 1-30.

NCM (2002): A practical approach to the application of the risk analysis process-illustrated with two models caffeine and Campylobacter. Nordic Council of Ministers, TemaNord 2002:510.

OfFice of Food Iceland (2002): Caffeine consumption in Iceland in 2002. The Environment and Food Agency in Iceland 2004, UST-2004:27. Available: http://www.mast.is/Uploads/document/Skyrslur/ caffeineconsumptionIceland2002.pdf

Pizza, C., Rastrelli, L., Totaro, K. \& De Simone, F. (1999): Paullinia cupana (guarana) determinazione degli alcaloidi xantinici per la valutazione della qualita' di prodotti base di guarana'. (Paullinia cupana (guarana): determination of xanthine alkaloids in order to set the value of products based guarana.) -in: Il Guarana' degli Indios Satere'-Maué, Istituto Italo-Latinoamericana, Rome: Serie Scienza 13, pp. 13-22.

Pollak, C.P. \& Bright, D. (2003): Caffeine consumption and weekly sleep patterns in US seventh-, eighth-, and ninthgraders. Pediatrics, 111, 42-46.

Rodler, I., Bíró, L., Greiner, E., Szórád, I., Varga, A., Domonkos, A., Ágoston, H., Balázs, A., Mozsáry, E., Vitrai, J., Herman, D., Boros, J., Németh, R. \& Kéki, Zs. (2005): Táplálkozási vizsgálat Magyarországon 2003-2004 (Dietary survey in Hungary). Orvosi Hetilap, 146, 1781-1789.

Sarkadi Nagy, E., Bakacs, M., Illés, É., Zentai, A., Lugasi, A. \& Martos, É. (2012): Országos Táplálkozás és Tápláltsági Állapot Vizsgálat - OTÁP2009. II. A magyar lakosság energia- és makrotápanyag bevitele (Hungarian Diet and Nutritional Status Survey - The OTAP2009 study. II. Energy and macronutrients intake of the Hungarian population). Orvosi Hetilap, 153, 1057-1067.

Sмiтh, A. (2002): Effects of caffeine on human behavior. Food Chem. Tox., 40, 1243-1255. 
Stavric, B., Klassen, R., Watkinson, B., Karpinski, K., Stapley, R. \& Fried, P. (1988): Variability in caffeine consumption from coffee and tea: possible significance for epidemiological studies. Food Chem. Toxicol., 26, $111-118$.

Szeitz-Szabó, M., Bíró, L., Bíró, Gy. \& Sali, J. (2011): Dietary survey in Hungary, 2009. Part I. Macronutrients, alcohol, caffeine, fibre. Acta Alimentaria, 40, 142-152.

Valek, M., Laslavic, B. \& Laslavic, Z. (2004): Daily caffeine intake among Osijek High School students: questionnaire study. Croatian Med. J., 45, 72-75.

Yamada, M., Sasaki, S., Murakami, K., Takahashi, Y., Okubo, H., Hirota, N., Notsu, A., Todoriki, H., Miura, A., FuKu, M. \& DATE, C. (2009): Estimation of caffeine intake in Japanese adults using $16 \mathrm{~d}$ weighed diet records based on a food composition database newly developed for Japanese population. Public Health Nutr., 13, $663-672$. 